\title{
Kreativitas Guru Dalam Memanfaatkan Berita Politik Sebagai Media Pembelajaran PPKn Kelas IX Di SMP Negeri 31 Padang
}

Rina Fitri, Al Rafni, Hasrul

Prodi Pendidikan Pancasila dan Kewarganegaraan

Universitas Negeri Padang

E-mail: fitririnrf@gmail.com

\begin{abstract}
ABSTRAK
Penelitian ini bertujuan 1) mendeskripsikan kreativitas guru dalam memanfaatkan berita politik sebagai media pembelajaran PPKn kelas IX di SMP Negeri 31 Padang. 2) mengidentifikasi kendala guru dalam memanfaatkan berita politik sebagai media pembelajaran PPKn kelas IX di SMP Negeri 31 Padang. Penelitian ini menggunakan pendekatan kualitatif dengan metode deskriptif. Hasil penelitian menunjukkan bahwa pertama bentuk kreativitas guru dalam memanfaatkan berita politik sebagai media pembelajaran PPKn dapat dilihat melalui lima tahap yaitu pada tahap perencanaan, tahap persiapan guru, tahap persiapan kelas, pelaksanaan pembelajaran dengan menggunakan media berita politik, dan tahap evaluasi. Kedua kendala guru dalam memanfaatkan media berita politik disebabkan oleh beberapa faktor diantaranya guru masih kesulitan dalam merumuskan indikator pembelajaran, fasilitas sekolah yang kurang mendukung, akses internet yang kurang lancar, alokasi waktu pembelajaran yang terlalu singkat, serta sebagian siswa kurang menyukai berita politik. Manfaat media berita politik terhadap pembelajaran PPKn diantaranya dapat menambah pengetahuan politik siswa, siswa dapat membedakan masalah politik dengan masalah lainnya, dan dapat mengetahui masalah politik pada saat sekarang. Selain itu, pembelajaran dengan menggunakan media berita politik membuat siswa lebih aktif dalam pembelajaran, siswa lebih termotivasi untuk mengikuti pembelajaran PPKn.
\end{abstract}

\section{Kata Kunci : berita politik, media pembelajaran}

\begin{abstract}
The goal of this study is 1) describe the creativity of teachers in using online political news as a medium of learning on civic education subject at Class IX in SMP Negeri 31 Padang. 2) identify the obstacles of teachers in using online political news as a medium of learning on civic education at Class IX in SMP Negeri 31 Padang. This research uses qualitative approach with descriptive method. The result of the research shows that the first form of teacher's creativity in using online politics news as a learning media of civic education can be seen through five stages: planning stage, preparatory phase of teacher, class preparation stage, learning implementation using political news media, and evaluation stage. Both teachers' obstacles in using the political news media are caused by several factors including teachers still difficulty in formulating learning indicators, less supportive school facilities, poor internet access, too short learning time allocation,
\end{abstract}


and some students are less fond of political news. The benefits of the news media politics on civic education subject can increase students' political knowledge, students can distinguish the political problems with other problems, and can know the current political problems. In addition, learning by using the political news media to make students more active in learning, students are more motivated to follow the learning of civic education subject.

\section{Keywords: Political News, Learning Media}

\section{PENDAHULUAN}

Pembelajaran adalah suatu kegiatan dalam proses pendidikan yang dijalankan untuk mencapai tujuan dari pendidikan. Salah satu tujuan pendidikan menurut Kartini Kartono (2009 : 82) ialah membentuk manusia susila yang cakap dan warganegara yang demokratis serta bertanggung jawab terhadap kesejahteraan masyarakat dan tanah air berdasarkan asas pancasila dan UUD Tahun 1945. Pendidikan diharapkan mampu melahirkan generasi yang memiliki ilmu pengetahuan, cakap dalam bertindak, tahu akan hak dan kewajibannya sebagai warga masyarakat, bangsa dan negara serta cinta akan negaranya. Pendidikan seperti ini bisa diperoleh oleh siswa melalui mata pelajaran pendidikan pancasila dan kewarganegaraan. Tujuan pendidikan kewarganegaraan menurut Komala Nurmalina (2008:3) adalah "mempersiapkan warga Negara yang kritis, analitis, aktif, bersikap dan bertindak demokratis". Maksudnya para peserta didik diharapkan memiliki sikap kemampuan berpikir kritis, rasional dan aktif agar ikut berpartispasi dalam membangun bangsa bersamaan dengan kecerdasan warganegara yang mengetahui akan hak da kewajibannya. Melihat begitu pentingnya pendidikan pancasila dan kewarganegaraan, hendaklah mata pelajaran PPKn menjadi salah satu mata pelajaran favorit bagi siswa. Namun, hal ini jarang sekali dijumpai di sekolah. Untuk itu, guru harus kreatif dalam menciptakan suasana belajar yang kondusif dan menyenangkan agar siswa tidak bosan dan menjadi aktif dalam proses pembelajaran. Kreativitas guru dapat dilihat dari inovasi dalam pembelajaran, misalnya penggunaan media pembelajaran.

Salah satu media yang bisa digunakan guru dalam pembelajaran PPKn adalah berita politik. Berita politik dapat dijadikan sebagai media dalam pembelajaran PPKn mengingat konten dari pelajaran PPKn mengenai politik, hukum dan pemerintahan. Berita politik merupakan salah satu komponen pengajaran yang memegang peranan penting dalam penyampaian pesan materi, sehingga dapat membantu siswa dalam memahami materi pelajaran (Lilin Halimah, 2014:68). 
Berdasarkan data yang
peneliti peroleh selama melaksanakan Praktek Lapangan Kependidikan (PLK) di SMPN 31 Padang, peneliti menemukan bahwa ada guru (X) PPKn di SMPN 31 Padang yang memanfaatkan berita sebagai media dalam pembelajaran pendidikan pancasila dan kewarganegaraan, berita yang digunakan adalah berita seputar politik, hukum dan pemerintahan. Berita politik yang digunakan diambil dari berita online seperti, mediaindonesia.com, bisnis.com, kabar24.com, Tempo.com, liputan6.com, kompas.com dan lain sebagainya. Namun, peneliti juga melihat bahwa pemanfaatan berita politik sebagai faktor diantaranya guru yang masih kesulitan dalam merumuskan indicator pembelajaran, fasilitas sekolah yang kurang mendukung, sebagian siswa yang kurang menyukai berita politik, dan sebagainya. Berangkat dari pemaparan tersebut, peneliti tertarik untuk melakukan penelitian yang diberi judul "Kreativitas Guru dalam Memanfaatkan Berita Politik sebagai Media Pembelajaran PPKn Kelas IX di SMP Negeri 31 Padang".

\section{METODE PENELITIAN}

Jenis penelitian ini adalah penelitian kualitatif dengan metode deskriptif. Jenis data yang digunakan adalah data primer dan data sekunder dengan pengumpulan data melalui wawancara, observasi dan dokumentasi. Teknik pengujian keabsahan data melalui teknik triangulasi. Analisis data dilakukan melalui reduksi data, display data dan verifikasi data.

\section{HASIL PENELITIAN}

\section{Bentuk Kreativitas Guru dalam Memanfaatkan Berita Politik sebagai Media Pembelajaran PPKn Kelas IX di SMP Negeri 31 Padang}

Berdasarkan temuan penelitian, bentuk kreativitas guru dalam memanfaatkan berita politik sebagai media pemelajaran dapat dilihat dalam lima tahap, yaitu :

\section{a. Tahap Perencanaan}

Berdasarkan temuan di lapangan, langkah pertama yang dilakukan guru $X$ dalam memanfaatkan berita politik sebagai media pembelajaran dimulai dengan perencanaan. Menurut guru X, dalam memanfaatkan berita politik sebagai media pembelajaran dimulai dengan perencanaan terlebih dahulu agar dalam proses pembelajaran berjalan dengan lancar. Perencanaannya yaitu melihat materi yang akan diajarkan, misalnya materinya tentang lembaga-lembaga Negara barulah disesuaikan berita yang akan digunakan sebagai media pembelajaran.

Dalam menyesuaikan materi pembelajaran dengan berita politik yang akan dijadikan media, langkah yang dilakukan oleh guru $\mathrm{X}$ adalah :

1) Menganalisis materi pelajaran yang sesuai dengan 
kompetensi dasar yang akan diajarkan. Ada dua kompetensi dasar yang dapat dipelajari dengan pemanfaatan berita politik sebagai media, yaitu KD 3.2 tentang memahami pokokpokok pikiran yang terkandung dalam pembukaan UUD Negara RI Tahun 1945, dan KD 3.3 tentang memahami prinsipprinsip kedaulatan sesuai UUD Negara RI Tahun 1945.

2) Merumuskan indikator dan menyesuaikan dengan berita politik yang akan digunakan sebagai media pembelajaran.

3) Membandingkan berita politik dari berbagai sumber yang akan dipilih menjadi sumber media berita politik. Dalam hal ini, guru $X$ membandingkan antara dua sumber berita politik yang akan digunakan sebagai media pembelajaran PPKn.

Indikator pertama tentang pemilihan umum sebagai perwujudan kedaulatan rakyat, berita yang dibandingkan adalah berita yang diambil dari mediaindonesia.com tentang KPU RI siapkan 2 draf payung hukum dengan berita pilpres 2019 calon tunggal atau calon jamak yang diambil dari kabar24.com. Sedangkan indikator kedua tentang lembaga tinggi Negara dan lembaga-lembaga pelaksana kedaulatan rakyat, berita yang dibandingkan tentang MPR rekomendasikan penguatan peran DPD (sumbernya liputan6.com) dengan ketua gerakan muda partai golkar mendeklarasikan golkar bersih didepan kantor DPD (sumbernya Tempo.com).

Dari satu indikator ada dua berita yang dibandingkan oleh $\mathrm{X}$ dimana kedua berita tersebut diperoleh dari sumber yang berbeda seperti mediaindonesia.com dengan kabar24.com, juga liputan6.com dengan Tempo.com.

\section{b. Tahap Persiapan Guru}

Pada tahap ini, ada beberapa hal yang dipersiapkan oleh $X$ dalam menggunakan berita politik sebagai media pembelajaran diantaranya :

1) menyiapkan materi pembelajaran yang sesuai dengan berita yang akan ditampilkan.

2) Menyiapkan media berita politik dalam bentuk powerpoint. Berita politik yang telah dibandingkan sebelumnya pada tahap perencanaan kemudian dipilih satu berita yang sesuai dengan materi pelajaran lalu dibuat dalam bentuk powerpoint.

3) Mempersiapkan kegiatan yang akan dilakukan siswa dalam pembelajaran yang dibuat dalam powerpoint.

4) menyiapkan evaluasi. Evaluasi disini ialah penilaian yang akan dilakukan oleh $\mathrm{X}$ sewaktu menggunakan media berita politik.

\section{c. Tahap Persiapan Kelas}

Persiapan kelas disini merupakan persiapan kelas yang dilakukan sebelum pembelajaran 
dengan media berita politik dimulai. Persiapan kelas yang dilakukan oleh $\mathrm{X}$ ialah mengatur duduk siswa, memastikan infokus yang akan digunakan masih berfungsi dengan baik karena tidak semua infokus yang ada di kelas IX masih bagus atau dengan kata lain sudah banyak yang rusak. Serta mengatur duduk siswa, biasanya siswa dibagi menjadi beberapa kelompok, namun tidak jarang siswa duduk seperti biasanya, serta duduk melengkung membentuk huruf $U$. Hal ini tergantung dengan keadaan kelas dan juga keinginan siswanya.

\section{d. Tahap \\ Pelaksanaan \\ Pembelajaran dengan \\ Menggunakan Media Berita Politik}

pada tahap penyajian pelajaran dengan memanfaatkan media berita politik ada beberapa tahap yang dilakukan diantaranya:

1) Mempersiapkan kelas, seperti membersihkan kelas terlebih dahulu. Siswa diminta untuk memungut sampah yang ada disekitar bangku mereka terlebih dahulu.

2) Berdo'a menurut agama masing-masing.

3) Menjelaskan kepada siswa tujuan pembelajaran dengan memanfaatkan berita politik.

4) Menjelaskan kepada siswa kegiatan apa saja yang akan dilakukan siswa selama proses pembelajaran seperti pengaturan tempat duduk, mengamati berita yag ditampilkan, berdiskusi, menganalisis dan mempresentasikan hasil analisis mereka.

5) Tayangan berita politik dalam bentuk slide ditampilkan dengan menggunakan infokus.

6) Siswa diminta untuk mengamati berita yang akan ditayangkan.

7) Lalu, siswa disuruh untuk mendiskusikan dengan teman sekelompoknya tentang berita politik yang sudah mereka baca.

8) Masing-masing kelompok diminta untuk mempresentasikan hasil analisis kelompoknya.

9) Guru menjelaskan keterkaitan berita politik dengan materi pembelajaran.

\section{e. Tahap Evaluasi/Penilaian}

Tahap evaluasi disini ialah tahap penilaian yang dilakukan oleh $X$ berdasarkan ketentuan yang sudah dibuat oleh $X$. Dimana penilaian yang dilakukan ialah penilaian langsung berupa pertanyaan yang diberikan kepada siswa pada saat proses pembelajaran berlangsung.

Dari pemaparan diatas terlihat kreativitas $\mathrm{X}$ dalam memanfaatkan berita politik sebagai media pembelajaran. Hal ini sesuai dengan teori yang dikemukakan oleh Bahri dan Zain (2006:136) bahwa ada lima langkah yang bisa ditempuh guru 
pada waktu mengajar dengan menggunakan media, yaitu :

a. Merumuskan tujuan pengajaran dengan memanfaatkan media atau tahap persiapan

b. Persiapan guru

c. Persiapan kelas

d. Langkah penyajian pelajaran dan pemanfaatan media

e. Langkah evaluasi pengajaran

2. Kendala

Guru

Memanfaatkan Berita Politik sebagai Media Pembelajaran PPKn Kelas IX di SMP Negeri 31 Padang

Temuan penelitian menunjukkan bahwa terdapat lima kendala guru $X$ dalam memanfaatkan berita politik sebagai media pembelajaran PPKn, yaitu :

a. Guru masih kesulitan dalam merumuskan indikator pembelajaran yang sesuai dengan pemanfaatan berita politik sebagai media pembelajaran.

b. Fasilitas sekolah yang kurang mendukung sperti infokus dan baahan bacaan berita (Koran) yang kurang.

c. Akses internet yang kurang lancar.

d. Alokasi waktu pembelajaran yang terlalu sngkat.

e. Sebagian siswa kurang menyukai berita politik.

Seperti yang dikatakan Bambang Warsita (2008:53), bahwa keuntungan bagi Sekolah yang memiliki kelengkapan sarana dan prasarana diantaranya,

a. Kelengkapan sarana dan prasarana dapat menumbuhkan gairah dan motivasi guru dalam mengajar.

b. Kelengkapan sarana dan prasarana dapat memberikan berbagai pilihan pada siswa untuk belajar. SMP Negeri 31 Padang dapat dikataka belum sepenuhnya memiliki fasilitas yang mendukung guru maupun siswa dalam menunjang proses pembelajaran.

\section{KESIMPULAN}

Berdasarkan analisis yang telah dilakukan, dapat disimpulkan bahwa tidak semua berita politik dapat dijadikan sebagai media pembelajaran, karena harus disesuaikan terlebih dahulu dengan materi yang akan dipelajari. Misalnya materi tentang pemilu, dilihat dulu apa tujuan pembelajarannya karena berita tentang pemilu sangat banyak. Contohnya tujuan pembelajarannya adalah pelaksanaan pemilu, maka berita yang dicari adalah berita pemilu tentang pelsanaannya.

Ada lima langkah bentuk kreatifitas guru dalam memanfaatkan berita politik sebagai media pembelajaran yaitu tahap perencanaan, langkah persiapan guru, langkah persiapan kelas, tahap penyajian pembelajaran dengan menggunakan media berita 
politik, serta tahap evaluasi pembelajaran. Dengan menggunakan berita politik sebagai media pembelajaran PPKn dapat meningkatkan motivasi dan minat belajar siswa, sehingga siswa menjadi antusias dalam belajar. Manfaat lain dari pemanfaatan berita politik sebagai media pembelajaran ialah dapat menambah pengetahuan politik siswa, siswa dapat membedakan masalah politik dengan masalah lainnya dan siswa dapat mengetahui masalah politik yang terjadi saat sekarang.
Terdapat enam kendala guru dalam memanfaatan berita politik sebagai media pembelajaran PPKn yaitu guru masih kesulitan dalam merumuskan indikator pembelajaran, fasilitas sekolah yang kurang mendukung, akses internet yang kurang lancar, jumlah siswa yang terlalu banyak dalam satu kelas, alokasi waktu pembelajaran yang terlalu singkat, serta sebagian siswa kurang menyukai berita politik.

\section{DAFTAR PUSTAKA}

Ananda, Azwar. 2012. Pendidikan Kewarganegaraan, Pendidikan Karakter Bangsa Dan Strategi Pembelajaran Nilai. Padang: UNP PRESS.

Arsyad, Azhar. 2010. Media Pembelajaran. Depok : Rajawali Pers.

Kustandi, Cecep \& Bambang S. 2011. Media Pembelajaran Manual Dan Digital. Bogor : Ghalila Indonesia.

Moleong, Lexy J. 2012. Metodologi Penelitian Kualitatif. Bandung : PT Remaja Rosdakarya.

Mulyasa. 2008. Menjadi Guru Professional : Menciptakan Pembelajaran Kreatif, Menyenangkan. Bandung : Remaja Rosdakarya.

Sadiman, Arief, Dkk. 2012. Media Pendidikan: Pengertian, Pengembangan Dan Pemanfaatannya. Depok : Rajawali Pers.

Acuan dari Jurnal :

Suryadi, Karim. 2007. "Pemanfaatan Berita Politik Di Kalangan Remaja Kota Bandung". Media Massa Dan Political Literacy. Vol. 8 No. 56/Dikti/Kep/2007.

\section{Acuan dari Skripsi :}

Halimah, Lilin. 2014. Pemanfaatan Berita Politik pada siaran TV Sebagai Media Pembelajaran Pendidikan Kewarganegaraan Kontekstual (Studi Deskriptif Di SMA PGRI 1 Subang Kelas X). Skripsi. Bandung : Universitas Pendidikan Indonesia.

Kurnia, D. 2010. Pemanfaatan Berita Politik Sebagai Media Stimulus Dalam Pkn Kontekstual (Studi Deskriptif Di SMA PGRI 1 Subang Kelas X). Skripsi. Bandung : Universitas Pendidikan Indonesia 